\title{
Article \\ Influences of Priming on Selected Physiological Attributes and Protein Pattern Responses of Salinized Wheat with Extracts of Hormophysa cuneiformis and Actinotrichia fragilis
}

\author{
Arafat Abdel Hamed Abdel Latef $1, *\left(\mathbb{D}\right.$, Abbu Zaid $^{2}{ }^{\mathbb{D}}$ and Eman A. Alwaleed ${ }^{3}$ \\ 1 Biology Department, Turabah University College, Turabah Branch, Taif University, P.O. Box 11099, \\ Taif 21944, Saudi Arabia \\ 2 Plant Physiology and Biochemistry Section, Department of Botany, Aligarh Muslim University, \\ Aligarh 202002, India; azaid@myamu.ac.in \\ 3 Botany and Microbiology Department, Faculty of Science, South Valley University, Qena 83523, Egypt; \\ eme_biologist@sci.svu.edu.eg \\ * Correspondence: a.moawd@tu.edu.sa or moawad76@gmail.com
}

check for updates

Citation: Abdel Latef, A.A.H.; Zaid, A.; Alwaleed, E.A. Influences of Priming on Selected Physiological Attributes and Protein Pattern Responses of Salinized Wheat with Extracts of Hormophysa cuneiformis and Actinotrichia fragilis. Agronomy 2021, 11, 545. https://doi.org/ 10.3390/agronomy11030545

Academic Editor: Vijay Joshi

Received: 12 February 2021

Accepted: 10 March 2021

Published: 13 March 2021

Publisher's Note: MDPI stays neutral with regard to jurisdictional claims in published maps and institutional affiliations.

Copyright: (C) 2021 by the authors. Licensee MDPI, Basel, Switzerland. This article is an open access article distributed under the terms and conditions of the Creative Commons Attribution (CC BY) license (https:/ / creativecommons.org/licenses/by/ $4.0 /)$.
Abstract: Biological effects of extracts obtained from the seaweeds Hormophysa cuneiformis (J.F.Gmelin) P.C.Silva and Actinotrichia fragilis (Forsskål) Bùrgesen were investigated using wheat for the improvement of growth and amelioration of the negative effects of soil salinity. Exposure of plants to salt stress resulted in an overall decrease in growth, chlorophyll a and b, carotenoids and soluble sugars, as well as nutrient uptake (i.e., $\mathrm{K}, \mathrm{Ca}$ and $\mathrm{Mg}$ ) and $\mathrm{K}^{+} / \mathrm{Na}^{+}$ratio. At the same time, increases were found in proline, total free amino acids, phenolic compounds, malondialdehyde (MDA), $\mathrm{Na}^{+}$ions, as well as the activities of peroxidase (POD), catalase (CAT), and superoxide dismutase (SOD). Priming wheat seeds with $H$. cuneiformis and $A$. fragilis extracts mitigated the negative impacts of salinity by enhancing growth and all the above attributes except MDA and $\mathrm{Na}^{+}$. Treatments with $\mathrm{H}$. cuneiformis or A. fragilis extracts resulted in an increased intensity of the polypeptide bands with 200, 159, 120, 40, and $22 \mathrm{KDa}$ which were already apparent in the control. A. fragilis showed higher effectiveness than H. cuneiformis extracts under both control and stressed regimes. Our results highlight "biofertilizer" properties of two seaweeds and furnish mechanistic insight into their salinity-improvement action, which is pertinent for both applied and basic research.

Keywords: Actinotrichia fragilis; antioxidant enzymes; growth; Hormophysa cuneiformis; protein patterns; salt stress; seaweed liquid fertilizers; Triticum aestioum

\section{Introduction}

Environmental stresses, including the spread of soil and water salinity, have a devastating effect on agricultural production [1-3]. Unfortunately, many regions around the world are facing a rapid increase in soil salinity. More than one-third of the world's arable land, or 950 million hectares of farmland, suffers from various levels of salinization [4,5]. It is estimated that over $50 \%$ of global arable land will be salinized by 2050 [6-9]. Wheat (Triticum aestivum L.) is amongst the major cereals which are cultivated and consumed, with a global production of about 635 million metric tons, the plant provides the calories needed by 4.5 billion people worldwide [10]. However, the production of wheat worldwide is affected by salinity stress [11]. Damage caused by salinity stress is reported to be more than $50 \%$ in different crop plants including wheat as reported by several researchers [12-14]. The response of plants to salinity is controlled by multiple genes and is therefore a very complex process [2]. Due to the genetic and physiological complexities of the salt tolerance trait, and lack of reliable and rapid screening assays, the production of salinity-resistant plant crops through genetic engineering has not been very successful [15-17].

The use of macroalgae as a commercial source of different bio-stimulants has attracted a lot of attention today in improving plant growth [18]. Seaweed extract is a well-known 
bio-stimulant, which improves the growth and function of various plants by improving nutrient uptake, enhancing root growth, and increasing foliage levels by improving the chlorophyll content. The positive effects of seaweed extracts are due to the presence of phytohormones and polysaccharides degraded to oligosaccharides which improve plant growth and development [19]. Varied applications of seaweed extracts showed significant improvement in plant tolerance against environmental stresses when compared to control plants [20]. The application of seaweed extracts has been reported to enhance the salt tolerance of some plants such as alfalfa [21] and chickpea [22].

The brown and red seaweeds Hormophysa cuneiformis and Actinotrichia fragilis belonging to Phaeophyceae and Rhodophyceae families, respectively, are amongst the most important algal flora along the Egyptian Red Sea coast, particularly associated with the cities of Hurghada and Safaga $[23,24]$. H. cuneiformis and A. fragilis are both environmentally friendly and promising sources for bioactive compounds, which can be very useful in agricultural management to improve agricultural products and control plant diseases $[25,26]$. However, more phytochemical studies on these interesting and rarely investigated seaweeds are still required to expand the little findings on their bioactive compounds. Accordingly, part of this research was devoted to detecting the bioactive substances of $H$. cuneiformis and $A$. fragilis using a gas chromatography-mass spectrometry (GC-MS) approach. On the other hand, there are numerous reports which showed the promising role of seaweeds in the abiotic stress tolerance of several crops. But until now there are no reports on the effect of $H$. cuneiformis and A. fragilis liquid extract on salt stress alleviation of wheat plants. Therefore, this study will give experimental evidence on the positive role of these seaweeds on the resistance of salt-stressed wheat plants.

\section{Materials and methods}

\subsection{Sampling and Extract Preparation}

H. cuneiformis (J.F.Gmelin) P.C.Silva and A. fragilis (Forsskål) Bùrgesen seaweeds (Figure 1) were collected from the Red Sea at Hurghada in July 2017. Harvested seaweeds were thoroughly washed with running tap water to remove all impurities, adhering sand particles, and epiphytes. They were placed in new polyethylene bags in an icebox containing slush ice. After this, the seaweeds were spread on blotting paper to remove excess water. The samples were dried in the sun for 7 days and then further dried at $80{ }^{\circ} \mathrm{C}$ for $24 \mathrm{~h}$. The dried seaweeds were then powdered by an electric mill. The powder of seaweed was boiled with water at 1:1 (w/v) for $2 \mathrm{~h}$. The homogenized solution was filtered with Whatman filter paper No. 2 and the extracts were kept in amber-colored bottles at $4{ }^{\circ} \mathrm{C}$ for the treatment of the wheat plants.

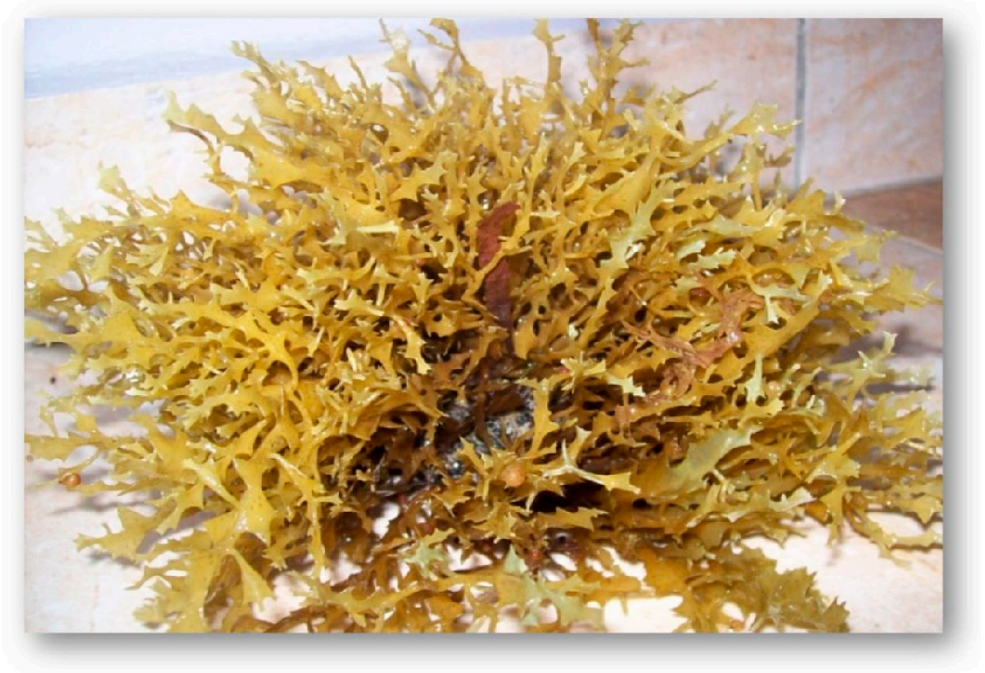

(A)

Figure 1. Cont. 


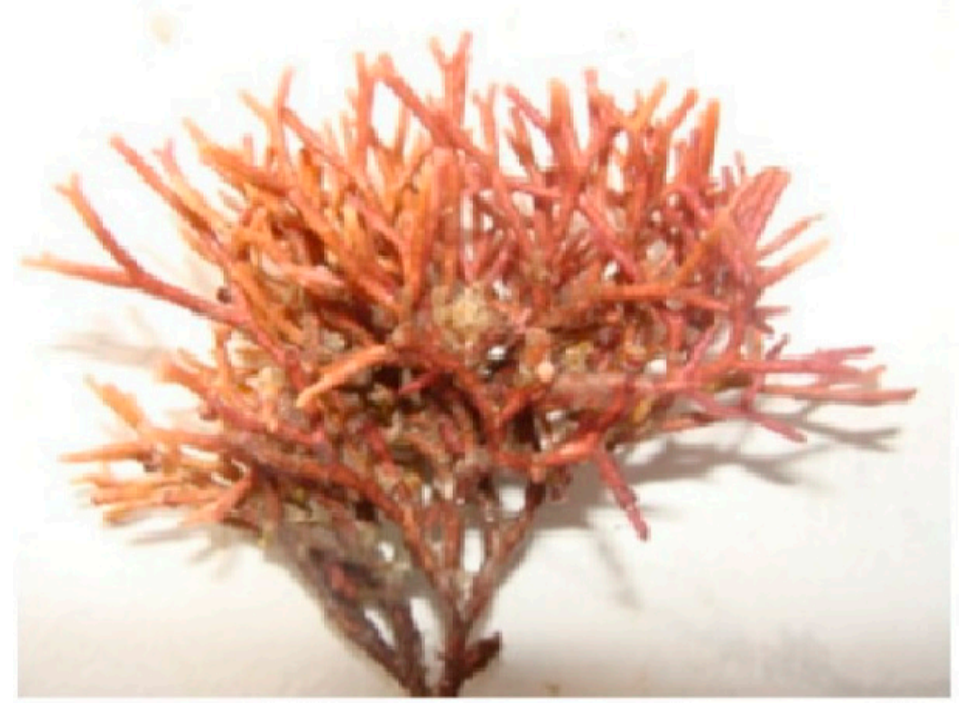

(B)

Figure 1. Collected seaweeds from Red Sea (A), H. cuneiformis, and (B), A. fragilis.

\subsection{Physico-Chemical and Biochemical Analysis of Seaweeds and Resulted Extracts}

The color and $\mathrm{pH}$ of both seaweed extracts were measured in the laboratory before preparation. Calcium, potassium, magnesium, and sodium were also estimated using a flame photometer (CORN NG 400, Mateo, CA, USA). Total carbohydrates in liquid extracts of both seaweeds were estimated by the anthrone sulphuric acid method [27]. Soluble proteins were determined according to [28] protocol. Total lipid content was analyzed following [29]. Physicochemical analysis of each seaweed extract is as shown below:

\begin{tabular}{ccc}
\hline Parameters & H. cuneiformis Extract & A. fragilis Extract \\
\hline Color & Brown & Red \\
PH & 6.8 & 6.8 \\
Magnesium & $100.24 \mathrm{mg} \mathrm{L}^{-1}$ & $120.00 \mathrm{mg} \mathrm{L}^{-1}$ \\
Calcium & $110.00 \mathrm{mg} \mathrm{L}^{-1}$ & $180.22 \mathrm{mg} \mathrm{L}^{-1}$ \\
Sodium & $176.00 \mathrm{mg} \mathrm{L}^{-1}$ & $206.00 \mathrm{mg} \mathrm{L}^{-1}$ \\
Potassium & $150.00 \mathrm{mg} \mathrm{L}^{-1}$ & $230.00 \mathrm{mg} \mathrm{L}^{-1}$ \\
Chloride & $200.50 \mathrm{mg} \mathrm{L}^{-1}$ & $350.00 \mathrm{mg} \mathrm{L}^{-1}$ \\
Phosphorus & $43.42 \mathrm{mg} \mathrm{L}^{-1}$ & $74.00 \mathrm{mg} \mathrm{L}^{-1}$ \\
Protein & $221.11 \mathrm{mg} \mathrm{L}^{-1}$ & $146.74 \mathrm{mg} \mathrm{L}^{-1}$ \\
Carbohydrate content & $352.77 \mathrm{mg} \mathrm{L}^{-1}$ & $305.82 \mathrm{mg} \mathrm{L}^{-1}$ \\
Lipid & $53.00 \mathrm{mg} \mathrm{L}^{-1}$ & $32.55 \mathrm{mg} \mathrm{L}^{-1}$ \\
\hline
\end{tabular}

\subsection{Seaweed Liquid Fertilizers and GC-MS Conditions}

H. cuneiformis and A. fragilis extracts were subjected to GC-MS analysis for their structural characterization. GC/MS analysis was accomplished using the GC instrument equipped with an HP-5MS column ( $30 \mathrm{~m} \times 250 \mu \mathrm{m} \times 0.25 \mu \mathrm{m}$ film thickness) and coupled with MS detector. The initial $\mathrm{T}$ of the device was kept at $90^{\circ} \mathrm{C}$ for $1 \mathrm{~min}$ then risen to $300{ }^{\circ} \mathrm{C}$ for $30 \mathrm{~min}$ at a rate of $8{ }^{\circ} \mathrm{C} \mathrm{min}-1$. Helium was used as a carrier gas. The volume of each sample was $1 \mu \mathrm{L}$ in the splitless mode per injection wherein the injector T was set at $290^{\circ} \mathrm{C}$. The mass spectrum was operated at $70 \mathrm{ev}$ and the mass range from 60-600 amu. The results of GC-MS were interpreted according to the database of the National Institute Standard and Technology (NIST). The range of recognized compounds in the NIST library was used to compare the spectrum of unknown compounds. The name, structure, and molecular weight of the detected components are presented in Table 1. 
Table 1. GC-MS profiles of phytochemical compounds of H. cuneiformis and A. fragilis extracts.

\begin{tabular}{|c|c|c|c|c|c|c|c|}
\hline \multirow{2}{*}{ No. } & \multirow[t]{2}{*}{ Compound Name } & \multicolumn{2}{|c|}{ Molecular Weight (M.W.) } & \multicolumn{2}{|c|}{ Formula } & \multicolumn{2}{|c|}{ Retention Time (R.T.) } \\
\hline & & H. cuneiformis & A Fragilis & H. cuneiformis & A Fragilis & H.cuneiformis & A Fragilis \\
\hline 1 & $\begin{array}{c}\text { Dodecanoic acid, methyl } \\
\text { ester (CAS) }\end{array}$ & 200 & 214 & $\mathrm{C}_{12} \mathrm{H}_{24} \mathrm{O}_{2}$ & $\mathrm{C}_{13} \mathrm{H}_{26} \mathrm{O}_{2}$ & 15.60 & 14.62 \\
\hline 2 & Heptadecane & 240 & - & $\mathrm{C}_{17} \mathrm{H}_{36}$ & - & 17.22 & - \\
\hline 3 & $\begin{array}{l}\text { Tetradecanoic acid, } \\
\text { methyl ester (CAS) }\end{array}$ & 242 & - & $\mathrm{C}_{15} \mathrm{H}_{30} \mathrm{O}_{2}$ & - & 17.77 & - \\
\hline 4 & Oleic acid & 282 & - & $\mathrm{C}_{18} \mathrm{H}_{34} \mathrm{O}_{2}$ & - & 18.26 & - \\
\hline 5 & octadecanoic acid 10 & 284 & - & $\mathrm{C}_{18} \mathrm{H}_{36} \mathrm{O}_{2}$ & - & 18.88 & - \\
\hline 6 & $\begin{array}{c}\text { Palmitic acid } \\
\text { (n-hexadecanoic acid } 1\end{array}$ & 256 & - & $\mathrm{C}_{16} \mathrm{H}_{32} \mathrm{O}_{2}$ & - & 19.23 & - \\
\hline 7 & $\begin{array}{l}\text { (E)-9-Octadecenoic acid } \\
\text { ethyl ester } \\
\text { 2-Hexadecen-1-ol, }\end{array}$ & 310 & - & $\mathrm{C}_{20} \mathrm{H}_{38} \mathrm{O}_{2}$ & - & 19.75 & - \\
\hline 8 & $\begin{array}{l}\text { 3,7,11,15-tetramethyl-, } \\
\left.\quad\left[R-\left[R^{*}, R^{*}-(E)\right]\right]-S\right)\end{array}$ & 296 & - & $\mathrm{C}_{20} \mathrm{H}_{40} \mathrm{O}$ & - & 19.82 & - \\
\hline 9 & $\begin{array}{l}\text { Hexadecenoic acid, } \\
\text { methyl ester }\end{array}$ & 270 & 270 & $\mathrm{C}_{17} \mathrm{H}_{34} \mathrm{O}_{2}$ & $\mathrm{C}_{17} \mathrm{H}_{34} \mathrm{O}_{2}$ & 20.53 & 20.56 \\
\hline 10 & Phytol, acetate & 338 & - & $\mathrm{C}_{22} \mathrm{H}_{42} \mathrm{O}_{2}$ & - & 22.22 & - \\
\hline 11 & $\begin{array}{l}\text { Cholestan-3-ol, } \\
\text { 2-methylene-, (3á,5à)- }\end{array}$ & 400 & - & $\mathrm{C}_{28} \mathrm{H}_{48} \mathrm{O}$ & - & 27.03 & - \\
\hline 12 & $\begin{array}{l}\text { Heptanoic acid, methyl } \\
\text { ester (CAS) }\end{array}$ & - & 144 & - & $\mathrm{C}_{8} \mathrm{H}_{16} \mathrm{O}$ & - & 5.99 \\
\hline 13 & $\begin{array}{c}\text { Nonanoic acid, methyl } \\
\text { ester (CAS) }\end{array}$ & - & 172 & - & $\mathrm{C}_{10} \mathrm{H}_{20} \mathrm{O}_{2}$ & - & 9.48 \\
\hline 14 & 2-Methyltetracosane & - & 352 & - & $\mathrm{C}_{25} \mathrm{H}_{52}$ & - & 11.25 \\
\hline 16 & $\begin{array}{l}\text { Tetradecanoic acid, } \\
\text { methyl ester (CAS) }\end{array}$ & - & 242 & - & $\mathrm{C}_{15} \mathrm{H}_{30} \mathrm{O}_{2}$ & - & 17.71 \\
\hline 17 & $\begin{array}{c}\text { Tetraneurin-A-diol } \\
\text { 2-[5-(2-Hydroxypropyl)- }\end{array}$ & - & 280 & - & $\mathrm{C}_{18} \mathrm{H}_{20} \mathrm{O}_{5}$ & - & 19.18 \\
\hline 18 & $\begin{array}{l}\text { tetrahydrofuran-2-yl]- } \\
\text { propionic } \\
\text { acid, t-butyl ester }\end{array}$ & - & 258 & - & $\mathrm{C}_{14} \mathrm{H}_{26} \mathrm{O}_{4}$ & - & 19.18 \\
\hline 19 & $\begin{array}{l}\text { 3,7,11,15-Tetramethyl-2- } \\
\text { hexadecen-1-ol }\end{array}$ & - & 296 & - & $\mathrm{C}_{20} \mathrm{H}_{40} \mathrm{O}$ & - & 19.52 \\
\hline 20 & Phytol, acetate & & 338 & & $\mathrm{C}_{22} \mathrm{H}_{42} \mathrm{O}_{2}$ & & 19.58 \\
\hline 21 & $\begin{array}{l}\text { 13-Heptadecyn-1-ol } \\
\text { Ethanol, 2-(9,12- }\end{array}$ & - & 252 & - & $\mathrm{C}_{17} \mathrm{H}_{32} \mathrm{O}$ & - & 19.77 \\
\hline 22 & $\begin{array}{c}\text { octadecadienyloxy)-, } \\
(\mathrm{Z}, \mathrm{Z})- \\
\text { 9,12,15-Octadecatrienoic }\end{array}$ & - & 310 & - & $\mathrm{C}_{20} \mathrm{H}_{38} \mathrm{O}_{2}$ & - & 20.08 \\
\hline 24 & $\begin{array}{l}\text { acid-2-phenyl-1,3-dioxan- } \\
\text { 5-yl ester }\end{array}$ & - & 440 & - & $\mathrm{C}_{28} \mathrm{H}_{40} \mathrm{O}_{4}$ & - & 20.36 \\
\hline 25 & $\begin{array}{l}\text { 11-Hexadecenoic acid, } \\
\text { methyl ester }\end{array}$ & - & 268 & - & $\mathrm{C}_{22} \mathrm{H}_{42} \mathrm{O}_{2}$ & - & 20.22 \\
\hline 26 & $\begin{array}{c}\text { Hexadecanoic acid, } \\
\text { 14-methyl-, methyl ester }\end{array}$ & - & 284 & - & $\mathrm{C}_{18} \mathrm{H}_{36} \mathrm{O}_{2}$ & - & 21.78 \\
\hline 27 & $\begin{array}{l}\text { 7,10,13-Eicosatrienoic acid, } \\
\text { methyl ester (CAS) }\end{array}$ & - & 320 & - & $\mathrm{C}_{21} \mathrm{H}_{36} \mathrm{O}_{2}$ & - & 24.83 \\
\hline
\end{tabular}

\subsection{Plant Materials, Growth Conditions and Treatments}

The trial was carried out on wheat (Triticum aestivum L.) using pot culture in the wire-house experimental farm of South Valley University, Qena, Egypt. Uniform wheat seeds were surface sterilized with $0.1 \% \mathrm{HgCl}_{2}$ for $5 \mathrm{~min}$ and then rinsed thrice with sterile distilled water. After washing and disinfection, the seeds were soaked for $12 \mathrm{~h}$ in the seaweed extracts with a concentration of $1 \%(v / v)$. The equal number of seaweed extracttreated and control seeds (i.e., 10 seed pot $^{-1}$ ) were sown in plastic pots $(30 \mathrm{~cm}$ diameter) 
filled with mixed, air-dried clay and sand (3:1). Seed germination and continued growth of seedlings were allowed under prevailing conditions of $\mathrm{T}$, light, and humidity. Ten days after seedling growth, five healthy and uniform plants were selected in each pot and immediately the salinity treatment began. Three replicates (three pots) were placed in each treatment. The salinity treatments included control (irrigated with water) as well as the pots irrigated with 100 and $150 \mathrm{mM} \mathrm{NaCl}$. On day 30, plants were harvested for measuring various parameters.

\subsection{Plant Growth Parameters and Pigment Contents}

To assess growth characteristics, fresh root and shoot samples (3 replicates) were weighed and then the specimens were placed in an oven at $80^{\circ} \mathrm{C}$ for $2-4$ days to achieve a constant dry weight. The method described by [30] was used to measure pigments such as chlorophyll a, chlorophyll b, and carotenoids in the wheat leaves.

\subsection{Content Organic Solutes and Phenolic Compounds}

The soluble sugars content was estimated by [27], soluble proteins [28], proline [31], total free amino acids [32], and phenolic compounds [33] were measured in the wheat shoot (3 replicates), based on previously reported standard methods.

\subsection{Measurement of the Content of $\mathrm{Na}^{+}, \mathrm{K}^{+}, \mathrm{Ca}^{2+}$ and $\mathrm{Mg}^{2+}$}

The content of $\mathrm{Na}^{+}, \mathrm{K}^{+}, \mathrm{Ca}^{2+}$, and $\mathrm{Mg}^{2+}$ was estimated from the dried wheat shoot (3 replicates) using a flame photometer (CORN NG 400, Mateo, CA, USA) according to the method of [34].

\subsection{Assay of Malondialdehyde and Activities of Enzymatic Antioxidants}

Any oxidative damage present in fresh wheat leaves ( 3 replicates) was estimated by measuring the content of malondialdehyde (MDA). This used the thiobarbituric acid (TBA) method as described by [35]. For measuring the activities of antioxidant enzymes, fresh leaf samples ( 3 replicates) were ground in liquid $\mathrm{N}_{2}$, and total proteins were extracted based on the previous experiment [36]. Peroxidase (POD; EC 1.11.1.7), superoxide dismutase (SOD; EC 1.15.1.1) and catalase (CAT; EC 1.11.1.6) activities were measured according to the protocols of [37-39], respectively.

\subsection{Protein Extraction and SDS-PAGE Electrophoresis}

Fresh leaf samples (3 replicates) were powdered and homogenated in an extraction buffer to isolate proteins. The protein concentration was quantified using the [28] method. The protein extracts were added to a buffer and the resulted mixture was heated at $100{ }^{\circ} \mathrm{C}$ for $3 \mathrm{~min}$. The supernatant was stored at $-20^{\circ} \mathrm{C}$. For the preparation of vertical polyacrylamide gels, two glass plates $(16.3 \times 14.3)$ were fixed in a vertical position. The fractionation procedure was carried out after [40] and modified [41] protocols. The final molecular weight of proteins was determined by comparing it with the standard marker (Gene Direx com).

\subsection{Statistical Analyses}

The experiment was conducted according to the one-way analysis of variance (ANOVA) with three replications. Mean comparisons were carried out by the least significant difference (LSD) test at the $p<0.05$ probability level. All data are presented as the means \pm standard deviation $( \pm \mathrm{SD})$ from the replicates. ANOVA and LSD tests were performed applying the statistical analysis system (SAS) software (Version 9.1; SAS Institute, Cary, NC, USA).

\section{Results}

\subsection{GC-MS Analysis of the Seaweed Extracts}

The GC-MS analysis of the methanolic extract of H. cuneiformis and A. fragilis revealed the presence of 11 and 16 compounds respectively (Table 1 ). The major compound present 
in the H. cuneiformis extract was lauric acid at 15.60 retention time (Figure 2A) and in terms of $A$. fragilis extract, the major compounds were hexadecanoic acid and methyl ester at 20.56 retention time (Figure 2B). Oleic acid (18.26 retention time) in H. cuneiformis extract and tetradecanoic acid, methyl ester (17.71 retention time) as well as hexadecanoic acid, 14-methyl-, methyl ester (21.78 retention time) in the A. fragilis extract were found to be the next compounds present at higher concentrations (Figure 2A,B).
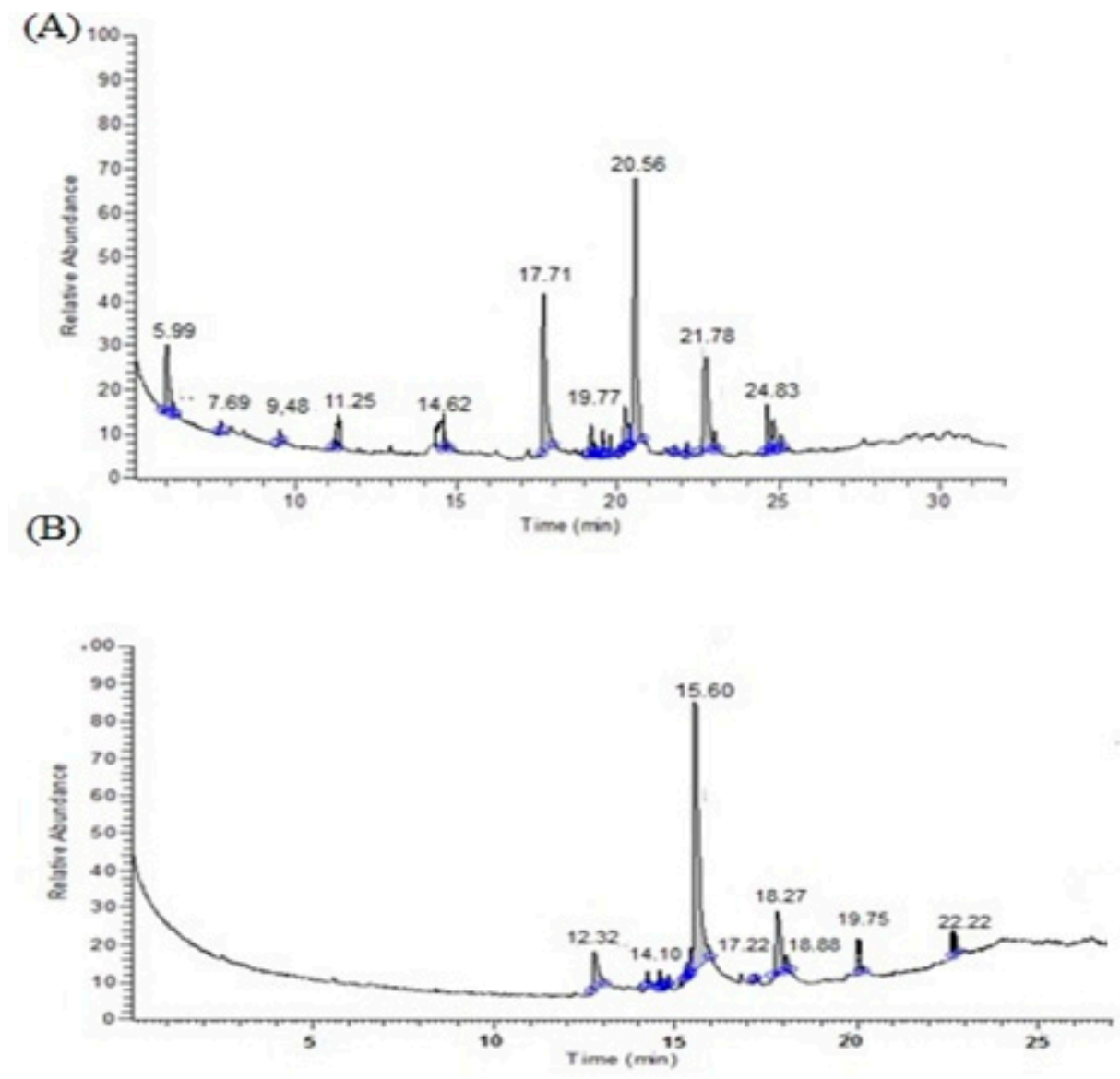

Figure 2. Gas chromatography-mass spectrometry (GC-MS) chromatogram of the methanolic extracts of $H$. cuneiformis (A) and $A$. fragilis (B).

\subsection{Plant Growth Parameters}

Under non-saline conditions, shoot and root fresh weights were increased by $13.29 \%$ and $15.65 \%$ in H. cuneiformis extract and $29.17 \%$ and $54.67 \%$ in A. fragilis extract-treated plants, while shoot and root dry weights were increased by $32.56 \%$ and $47.27 \%$ in H. cuneiformis extract and $25 \%$ and $50 \%$ in A. fragilis extract-treated plants respectively, as compared with that of the control. Exposure of wheat plants to salt stress resulted in an overall decrease in the fresh and dry weight of the roots and shoots. At $150 \mathrm{mM} \mathrm{NaCl}$, shoot fresh and dry weights were reduced by $88.31 \%$ and $72.41 \%$, root fresh and dry weight declined by $55.88 \%$ and $83.33 \%$, respectively, as compared with those of non-salt stressed plants. Priming with H. cuneiformis extract caused $32.67 \%$ and $48.21 \%$ increase in shoot fresh and dry weights, while $A$. fragilis extract treatments resulted in $37.04 \%$ and $61.33 \%$ increase in root fresh and dry weight, respectively, versus salinized plants (Figure 3). 

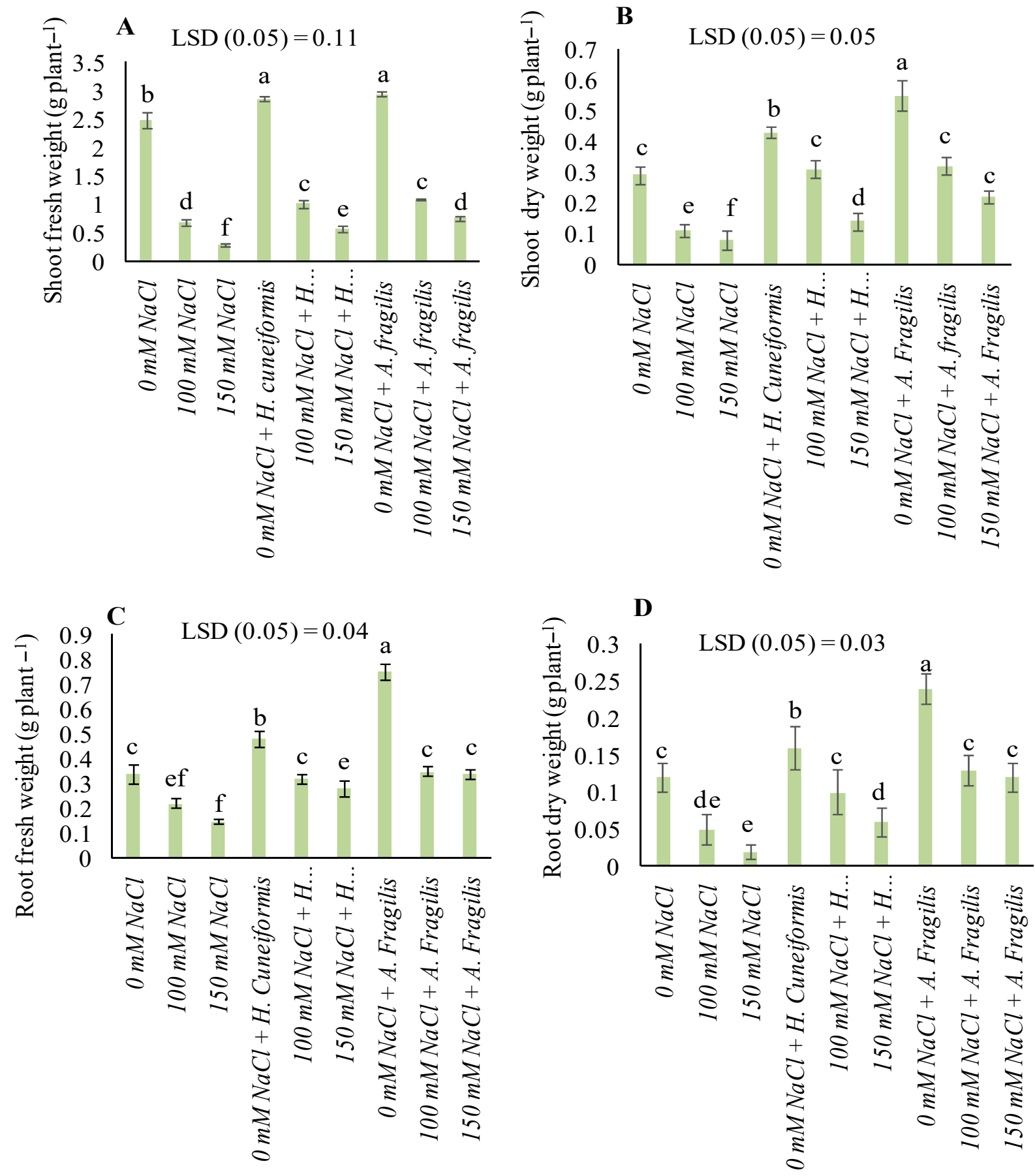

Figure 3. The effect of salinity stress on shoot fresh weight (A), shoot dry weight (B), root fresh weight (C) and root dry weight (D) of wheat (Triticum aestivum L.) primed with H. cuneiformis and A. fragilis extracts. Treatments include $0 \mathrm{mM} \mathrm{NaCl}$, $100 \mathrm{mM} \mathrm{NaCl}, 150 \mathrm{mM} \mathrm{NaCl}, 0 \mathrm{mM} \mathrm{NaCl}+$ H. cuneiformis, $100 \mathrm{mM} \mathrm{NaCl}+$ H. cuneiformis, $150 \mathrm{mM} \mathrm{NaCl}+\mathrm{H}$. cuneiformis, $0 \mathrm{mM} \mathrm{NaCl}+$ A. fragilis, $100 \mathrm{mM} \mathrm{NaCl}+$ A. fragilis, $0 \mathrm{mM} \mathrm{NaCl}+$ A. fragilis. Different letters for each mean show statistically significant differences according to the least significant difference (LSD) test $(p<0.05)$.

\subsection{Content of Pigments}

Exposure to salinity stress caused a significant decrease in chlorophyll $\mathrm{a}, \mathrm{b}$ and carotenoid contents, as compared to plants grown under normal conditions (Figure 4A-C). The priming with both seaweed extracts caused significant improvement of these pigments under salinity stress (Figure 4). At the highest $\mathrm{NaCl}$ level $(150 \mathrm{mM})$, chlorophyll a was increased by $13.79 \%$ and $20.21 \%$, chlorophyll b by $35.19 \%$ and $51.39 \%$, and carotenoids by 
$34.38 \%$ and $51.16 \%$ when treated by H. cuneiformis and A. fragilis extracts, respectively, as compared to stressed plants (Figure 4). The results in Figure 4 showed that the effect of A. fragilis extraction on improving the pigment contents of wheat leaves was much better than that of H. cuneiformis extract.
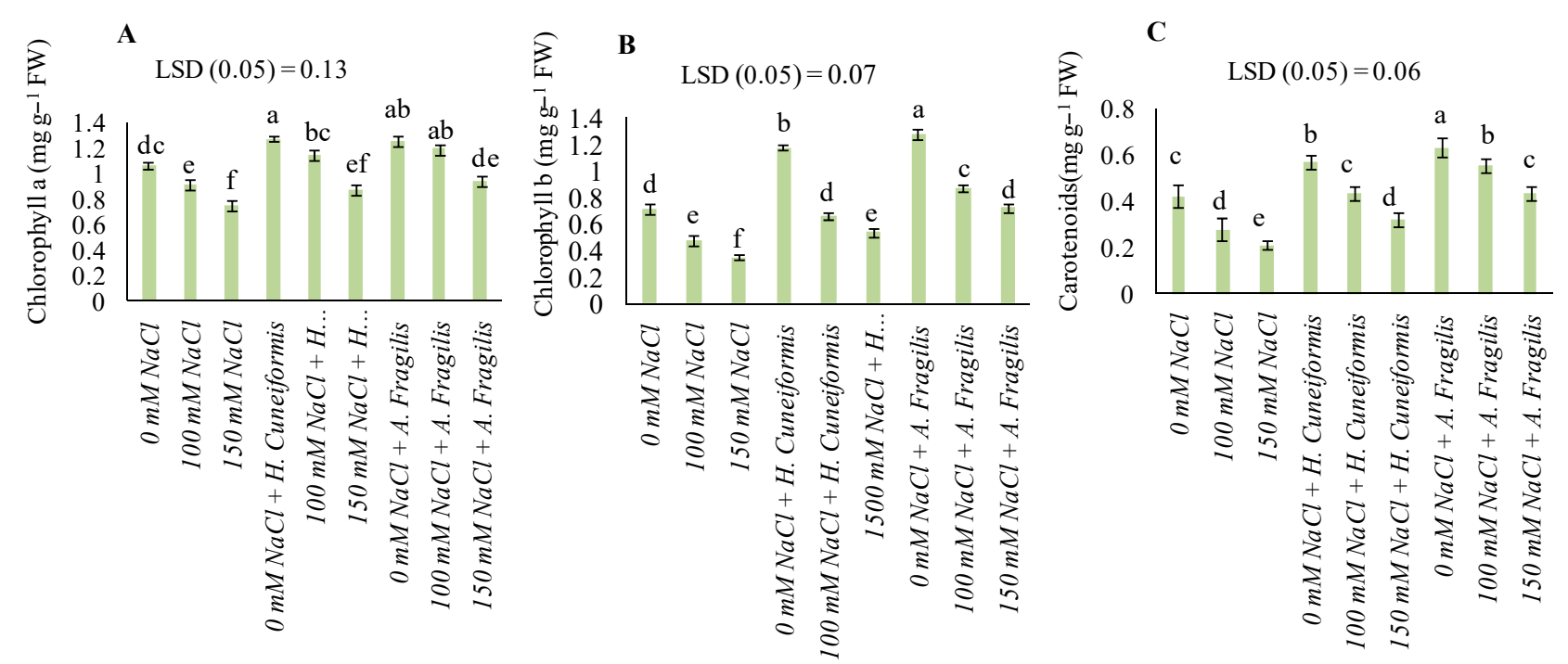

Figure 4. The effect of salinity stress on chlorophyll a (A), chlorophyll b (B) and carotenoids (C) in wheat (Triticum aestivum L.) primed with $H$. cuneiformis and $A$. fragilis extracts. Treatments include $0 \mathrm{mM} \mathrm{NaCl}, 100 \mathrm{mM} \mathrm{NaCl}, 150 \mathrm{mM} \mathrm{NaCl}, 0 \mathrm{mM}$ $\mathrm{NaCl}+H$. cuneiformis, $100 \mathrm{mM} \mathrm{NaCl}+$ H. cuneiformis, $150 \mathrm{mM} \mathrm{NaCl}+$ H. cuneiformis, $0 \mathrm{mM} \mathrm{NaCl}+$ A. fragilis, $100 \mathrm{mM} \mathrm{NaCl}$ $+A$. fragilis, $0 \mathrm{mM} \mathrm{NaCl}+A$. fragilis. Different letters for each mean show statistically significant differences according to the least significant difference (LSD) test $(p<0.05)$.

\subsection{Osmolytes and Phenolic Contents}

When no salinity stress was imposed, both $H$. cuneiformis and A. fragilis extract treatments increased the contents of soluble sugars, soluble proteins, total free amino acid accumulation, and phenolic compounds (Table 2). In H. cuneiformis extract-treated plants, soluble sugars, protein, total free amino acids, and phenolic compounds showed $22.82 \%$, $9.26 \%, 65.68 \%$, and $69.91 \%$ increases, while in A. fragilis extract-treated plants, these parameters were increased by $35.78 \%, 3.07 \%, 54.53 \%$, and $95.87 \%$, respectively, relative to the control plants (Table 2). Under increased salt concentrations (i.e., 100 and $150 \mathrm{mM}$ ), soluble proteins, proline accumulation, total free amino acid contents, and phenolic compounds showed a significant increase in treated plant tissues, although soluble sugars decreased in response to salinity stress (Table 2). However, treating $\mathrm{NaCl}$-stressed plants with both $\mathrm{H}$. cuneiformis and $A$. fragilis extracts ameliorated the negative effects of salinity by preventing further reductions in the above-mentioned parameters. At $150 \mathrm{mM} \mathrm{NaCl}$, soluble sugars, soluble proteins, total free amino acids contents and phenolic compounds showed $1.52 \%$, $39.37 \%, 24.48 \%$, and $13.08 \%$ increase in H. cuneiformis extract-treated plants and $4.32 \%$, $61.67 \%, 8.30 \%$, and $53.33 \%$ increase in A. fragilis extract-treated plants, as compared to stressed plants (Table 2). 
Table 2. The effect of salinity stress on soluble sugars (SS, $\mathrm{mg} \mathrm{g}^{-1} \mathrm{DW}$ ), soluble proteins (SP, $\mathrm{mg} \mathrm{g}^{-1} \mathrm{FW}$ ), proline content (Pro, $\mathrm{\mu g} \mathrm{g}^{-1} \mathrm{FW}$ ), total free amino acids (TFAA, $\mathrm{mg} \mathrm{g}^{-1} \mathrm{FW}$ ) and phenolic compounds (nmol g ${ }^{-1} \mathrm{FW}$ ) of wheat (Triticum aestivum L.) primed with $H$. cuneiformis and A. fragilis extracts.

\begin{tabular}{|c|c|c|c|c|c|}
\hline Treatments & SS & SP & Pro & TFAA & $\begin{array}{l}\text { Phenolic } \\
\text { Compounds }\end{array}$ \\
\hline $0 \mathrm{mM} \mathrm{NaCl}$ & $43.15 \pm 0.82 \mathrm{~d}$ & $27.53 \pm 3.25 \mathrm{~h}$ & $7.86 \pm 0.97 \mathrm{bcd}$ & $9.15 \pm 1.12 \mathrm{e}$ & $10.17 \pm 0.38 \mathrm{~h}$ \\
\hline $100 \mathrm{mM} \mathrm{NaCl}$ & $29.54 \pm 1.59 \mathrm{e}$ & $55.19 \pm 4.83$ ef & $11.02 \pm 2.52 \mathrm{~b}$ & $12.13 \pm 1.46 \mathrm{de}$ & $20.54 \pm 0.24 \mathrm{e}$ \\
\hline $150 \mathrm{mM} \mathrm{NaCl}$ & $29.31 \pm 3.45 \mathrm{e}$ & $62.41 \pm 1.84 \mathrm{~cd}$ & $14.83 \pm 3.58 \mathrm{a}$ & $19.77 \pm 1.76 \mathrm{~b}$ & $25.07 \pm 1.10 \mathrm{~d}$ \\
\hline $0 \mathrm{mM} \mathrm{NaCl}+H$. cuneiformis & $53.00 \pm 2.66 \mathrm{c}$ & $30.08 \pm 2.39 \mathrm{~h}$ & $4.41 \pm 1.45 \mathrm{e}$ & $15.16 \pm 2.28 \mathrm{~cd}$ & $17.28 \pm 0.25 \mathrm{f}$ \\
\hline $100 \mathrm{mM} \mathrm{NaCl}+H$. cuneiformis & $50.26 \pm 1.78 c$ & $58.43 \pm 2.30 \mathrm{de}$ & $8.44 \pm 1.19 \mathrm{bcd}$ & $19.69 \pm 2.39 b$ & $24.66 \pm 0.80 \mathrm{~d}$ \\
\hline $150 \mathrm{mM} \mathrm{NaCl}+\mathrm{H}$. cuneiformis & $43.81 \pm 1.35 \mathrm{~d}$ & $65.90 \pm 4.61 \mathrm{bc}$ & $10.07 \pm 1.67 \mathrm{bc}$ & $20.54 \pm 1.67 \mathrm{~b}$ & $28.35 \pm 0.73 c$ \\
\hline $0 \mathrm{mM} \mathrm{NaCl}+$ A. fragilis & $58.59 \pm 1.65 \mathrm{a}$ & $31.53 \pm 2.41 \mathrm{~h}$ & $3.92 \pm 1.87 \mathrm{e}$ & $14.14 \pm 4.62 \mathrm{~d}$ & $19.92 \pm 0.95 \mathrm{f}$ \\
\hline $100 \mathrm{mM} \mathrm{NaCl}+A$. fragilis & $53.22 \pm 2.68 \mathrm{bc}$ & $68.04 \pm 2.82 \mathrm{ab}$ & $6.78 \pm 2.22$ cde & $20.16 \pm 2.08 b$ & $30.60 \pm 0.61 b$ \\
\hline $150 \mathrm{mM} \mathrm{NaCl}+A$. fragilis & $40.70 \pm 2.40 \mathrm{~d}$ & $72.04 \pm 4.09 \mathrm{a}$ & $10.45 \pm 1.46 b$ & $28.21 \pm 2.27 \mathrm{a}$ & $38.44 \pm 0.50 \mathrm{a}$ \\
\hline LSD & 3.90 & 5.21 & 3.32 & 3.92 & 1.04 \\
\hline
\end{tabular}

Results are means $\pm \mathrm{SD}(n=3)$. Different letters for each mean show statistically significant differences at $p<0.05$ according to the least significant difference (LSD).

\section{5. $\mathrm{Na}^{+}, \mathrm{K}^{+}, \mathrm{Ca}^{2+}$ and $\mathrm{Mg}^{2+}$ Uptake}

Salinity increased the accumulation of $\mathrm{Na}^{+}$ions in the treated wheat plants whilst also reducing the absorption of $\mathrm{K}^{+}, \mathrm{Ca}^{2+}$, and $\mathrm{Mg}^{2+}$ compared to stress-free plants. Without salinity stress, the uptake of $\mathrm{Na}^{+}$by wheat plants was reduced by $52.20 \%$ and $49.88 \%$ with $H$. cuneiformis and $A$. fragilis extracts, respectively. The amount of $\mathrm{K}^{+}, \mathrm{Ca}^{2+}$, and $\mathrm{Mg}^{2+}$ absorbed by the plants also increased by $12.43 \%, 46.99 \%$, and $71.89 \%$ with H. cuneiformis extract and by $65.03 \%, 68.55 \%$, and $55.17 \%$ with $A$. fragilis extract, respectively (Table 3 ). At $150 \mathrm{mM} \mathrm{NaCl}, \mathrm{Na}^{+}$accumulation in wheat plants was reduced by $11.85 \%$ with the $H$. cuneiformis extract and by $25.93 \%$ with the $A$. fragilis extract. $\mathrm{K}^{+}, \mathrm{Ca}^{2+}$, and $\mathrm{Mg}^{2+}$ uptake in treated wheat increased by $70.16 \%, 88.80 \%$, and $22.68 \%$ with application of the H. cuneiformis extract and $33.54 \%, 87.46 \%$, and $57.90 \%$ with the A. fragilis extract treatment (Table 3).

Table 3. The effect of salinity stress on leaf nutrient contents $\left(\mathrm{mg} \mathrm{g}^{-1} \mathrm{DW}\right)$ of wheat (Triticum aestivum L.) primed with $H$. cuneiformis and A. fragilis extracts.

\begin{tabular}{cccccc}
\hline Treatments & $\mathbf{N a}^{+}$ & $\mathbf{K}^{+}$ & $\mathbf{K}^{+} / \mathbf{N a}^{+}$ & $\mathbf{C a}^{\mathbf{2 +}}$ & $\mathbf{M g}^{\mathbf{2 +}}$ \\
\hline $0 \mathrm{mM} \mathrm{NaCl}$ & $21.99 \pm 4.57 \mathrm{de}$ & $23.65 \pm 3.54 \mathrm{de}$ & $1.12 \pm 0.38 \mathrm{de}$ & $13.96 \pm 0.56 \mathrm{~g}$ & $14.48 \pm 0.50 \mathrm{e}$ \\
$100 \mathrm{mM} \mathrm{NaCl}$ & $32.66 \pm 2.31 \mathrm{~b}$ & $14.74 \pm 1.86 \mathrm{f}$ & $0.45 \pm 0.06 \mathrm{fg}$ & $12.22 \pm 0.47 \mathrm{~h}$ & $7.92 \pm 0.34 \mathrm{f}$ \\
$150 \mathrm{mM} \mathrm{NaCl}$ & $38.99 \pm 7.53 \mathrm{a}$ & $12.67 \pm 2.46 \mathrm{f}$ & $0.33 \pm 0.08 \mathrm{~g}$ & $8.22 \pm 0.29 \mathrm{i}$ & $7.14 \pm 0.65 \mathrm{f}$ \\
$0 \mathrm{mM} \mathrm{NaCl}+$ H. cuneiformis & $10.73 \pm 2.10 \mathrm{~g}$ & $26.59 \pm 4.22 \mathrm{bcd}$ & $2.49 \pm 0.11 \mathrm{~b}$ & $20.52 \pm 0.50 \mathrm{~b}$ & $39.37 \pm 0.94 \mathrm{a}$ \\
$100 \mathrm{mM} \mathrm{NaCl}+$ H. cuneiformis & $22.32 \pm 3.20 \mathrm{de}$ & $22.74 \pm 2.99 \mathrm{de}$ & $1.04 \pm 0.23 \mathrm{def}$ & $17.30 \pm 0.43 \mathrm{~d}$ & $29.00 \pm 1.0 \mathrm{~d}$ \\
$150 \mathrm{mM} \mathrm{NaCl}+$ H. cuneiformis & $34.37 \pm 2.73 \mathrm{ab}$ & $21.56 \pm 1.46 \mathrm{de}$ & $0.63 \pm 0.02 \mathrm{efg}$ & $15.52 \pm 0.46 \mathrm{f}$ & $30.18 \pm 1.05 \mathrm{~cd}$ \\
$0 \mathrm{mM} \mathrm{NaCl}+$ A. fragilis & $11.02 \pm 1.68 \mathrm{~g}$ & $39.03 \pm 2.53 \mathrm{a}$ & $3.60 \pm 0.68 \mathrm{a}$ & $23.53 \pm 0.34 \mathrm{a}$ & $36.95 \pm 6.04 \mathrm{ab}$ \\
$100 \mathrm{mM} \mathrm{NaCl}+$ A. fragilis & $19.69 \pm 1.85 \mathrm{ef}$ & $31.39 \pm 2.61 \mathrm{~b}$ & $1.61 \pm 0.28 \mathrm{~cd}$ & $16.51 \pm 0.49 \mathrm{e}$ & $33.55 \pm 1.50 \mathrm{bc}$ \\
$150 \mathrm{mM} \mathrm{NaCl}+$ A. fragilis & $28.88 \pm 2.68 \mathrm{bc}$ & $29.59 \pm 4.07 \mathrm{bc}$ & $1.06 \pm 0.11 \mathrm{def}$ & $15.41 \pm 0.52 \mathrm{f}$ & $32.48 \pm 0.17 \mathrm{c}$ \\
LSD & 5.99 & 5.47 & 0.65 & 0.77 & 3.46 \\
\hline
\end{tabular}

Results are means $\pm \mathrm{SD}(n=3)$. Different letters for each mean show statistically significant differences at $p<0.05$ according to the least significant difference (LSD).

\subsection{Oxidative Damage and Antioxidant Enzyme Activities}

Under non-stressed conditions, MDA accumulation was reduced by $33.12 \%$ and $29.53 \%$ with treatments by the $H$. cuneiformis and A. fragilis extracts, respectively, compared to the control (Table 4). POD, CAT, and SOD activities were increased by $23.91 \%, 10.51 \%$, and $9.68 \%$ with the $H$. cuneiformis extract and $82.91 \%, 41.14 \%$, and $15.54 \%$ with the $A$. fragilis extract, respectively (Table 4 ). When wheat plants were exposed to salinity stress, MDA accumulation was increased. At $150 \mathrm{mM} \mathrm{NaCl}$, MDA accumulation was enhanced by $169.35 \%$, as compared to the non-salt stressed controls (Table 4). At $150 \mathrm{mM} \mathrm{NaCl}, \mathrm{POD}$, 
CAT, and SOD activities were also increased by $65.83 \%, 9.13 \%$, and $9.07 \%$ with application of H. cuneiformis extract, and $111.49 \%, 10.33 \%$, and $10.13 \%$ with A. fragilis extract. At the same time, the MDA content decreased by $160.53 \%$ with the $H$. cuneiformis extract treatment and $143.03 \%$ with the $A$. fragilis extract, respectively. It is obvious from the above results that there was a positive effect of $A$. fragilis on increasing enzyme activity and decreasing MDA accumulation in response to all salinity concentrations and that this performance was greater than that of wheat responses to the H. cuneiformis extract under similar conditions (Table 4).

Table 4. The effect of salinity stress on malondialdehyde (nmole MDA $\mathrm{g}^{-1} \mathrm{FW}$ ), peroxidase activity ( $\mu$ mole POD $\mathrm{min}^{-1} \mathrm{mg}^{-1}$ protein), catalase activity ( $\mu$ mole CAT $\mathrm{min}^{-1} \mathrm{mg}^{-1}$ protein) and superoxide dismutase activity ( $\mu$ mole SOD $\min ^{-1} \mathrm{mg}^{-1}$ protein) of wheat (Triticum aestivum L.) primed with H. cuneiformis and A. fragilis extracts.

\begin{tabular}{ccccc}
\hline Treatments & MDA & POD & CAT & SOD \\
\hline $0 \mathrm{mM} \mathrm{NaCl}$ & $41.25 \pm 0.54 \mathrm{f}$ & $3.22 \pm 0.22 \mathrm{f}$ & $5.42 \pm 0.52 \mathrm{i}$ & $4.44 \pm 0.51 \mathrm{f}$ \\
$100 \mathrm{mM} \mathrm{NaCl}$ & $81.26 \pm 0.78 \mathrm{~b}$ & $4.66 \pm 0.41 \mathrm{~d}$ & $7.20 \pm 0.27 \mathrm{fg}$ & $5.25 \pm 0.27 \mathrm{e}$ \\
$150 \mathrm{mM} \mathrm{NaCl}$ & $111.11 \pm 1.17 \mathrm{a}$ & $4.93 \pm 0.06 \mathrm{~cd}$ & $9.00 \pm 0.11 \mathrm{~d}$ & $6.17 \pm 0.21 \mathrm{~d}$ \\
$0 \mathrm{mM} \mathrm{NaCl}+$ H. cuneiformis & $27.59 \pm 0.52 \mathrm{i}$ & $3.99 \pm 0.11 \mathrm{e}$ & $5.99 \pm 0.11 \mathrm{~h}$ & $4.87 \pm 0.14 \mathrm{ef}$ \\
$100 \mathrm{mM} \mathrm{NaCl}+$ H. cuneiformis & $58.63 \pm 1.19 \mathrm{~d}$ & $5.20 \pm 0.26 \mathrm{c}$ & $8.45 \pm 0.45 \mathrm{de}$ & $7.26 \pm 0.31 \mathrm{c}$ \\
$150 \mathrm{mM} \mathrm{NaCl}+$ H. cuneiformis & $66.22 \pm 0.70 \mathrm{c}$ & $5.34 \pm 0.15 \mathrm{c}$ & $10.37 \pm 0.39 \mathrm{~b}$ & $8.47 \pm 0.50 \mathrm{~b}$ \\
$0 \mathrm{mM} \mathrm{NaCl}+$ A. fragilis & $29.07 \pm 0.89 \mathrm{~h}$ & $5.89 \pm 0.11 \mathrm{~b}$ & $7.65 \pm 0.27 \mathrm{f}$ & $5.13 \pm 0.23 \mathrm{e}$ \\
$100 \mathrm{mM} \mathrm{NaCl}+$ A. fragilis & $58.53 \pm 0.81 \mathrm{~d}$ & $6.55 \pm 0.29 \mathrm{a}$ & $9.67 \pm 0.29 \mathrm{c}$ & $7.41 \pm 0.09 \mathrm{c}$ \\
$150 \mathrm{mM} \mathrm{NaCl}+$ A. fragilis & $59.00 \pm 0.00 \mathrm{~d}$ & $6.81 \pm 0.23 \mathrm{a}$ & $11.40 \pm 0.44 \mathrm{a}$ & $9.33 \pm 0.42 \mathrm{a}$ \\
LSD & 1.37 & 0.41 & 0.56 & 0.53 \\
\hline
\end{tabular}

Results are means $\pm \mathrm{SD}(n=3)$. Different letters for each mean show statistically significant differences at $p<0.05$ according to least significant difference (LSD).

\subsection{Protein Patterns}

In the present study, the distribution of protein bands in the SDS-PAGE profile (Figure 5) showed that the main polypeptide bands were scattered between 10-200 KDa. The variations in protein electrophoretic patterns under salinity stress in combination with seaweed extract in treated wheat plants and salinity in combination with seaweed extracts were presented as the appearance of new polypeptide bands and disappearance of other bands. Major polypeptide differences were observed between the control and other treatments (salinity, seaweed extracts, and combined salinity and seaweed extracts treatments). In particular, changes in two polypeptides bands with 200 and $40 \mathrm{KDa}$ molecular weights were identified. The polypeptide bands with 200, 159, 40, and $22 \mathrm{KDa}$ molecular weight were the most prominent in the control (first lane). The changes in $\mathrm{NaCl}$-stressed plants (indicated as lane 4), as compared with the non-stressed plants (control), showed a substantial increase in the levels of polypeptide bands indicative of a molecular weight of $200 \mathrm{KDa}$ and with a highly significant increase of $40 \mathrm{KD}$ polypeptides. One polypeptide band with $120 \mathrm{KDa}$ molecular weight was observed in plants subjected to $\mathrm{NaCl}$ stress which was not detectable in the control, while the $15 \mathrm{KDa}$ polypeptide was slightly reduced. Treatments with H. cuneiformis or A. fragilis extracts (as indicated in lanes 2 and 3, respectively) generally resulted in an increased intensity of most polypeptide bands which were already apparent in the control (i.e., untreated plants with seaweed extracts). The synthesis of one new protein with a molecular weight of $120 \mathrm{KDa}$ was also observed, in addition to another $40 \mathrm{KDa}$ in the case of $A$. fragilis extract. In salt-stressed plants (lane 4 ), the polypeptide with a $15 \mathrm{KDa}$ molecular weight became less obvious, and when those plants were treated with H. cuneiformis or A. fragilis extracts (lanes 5 and 6), it completely disappeared. The changes in protein-banding patterns, in response to wheat treatment with seaweed extracts, revealed the occurrence of 20 protein bands, ranging from 9-200 KDa in the control plants and 22 and 23 protein bands in response to H. cuneiformis or A. fragilis extracts respectively (Figure 5). 


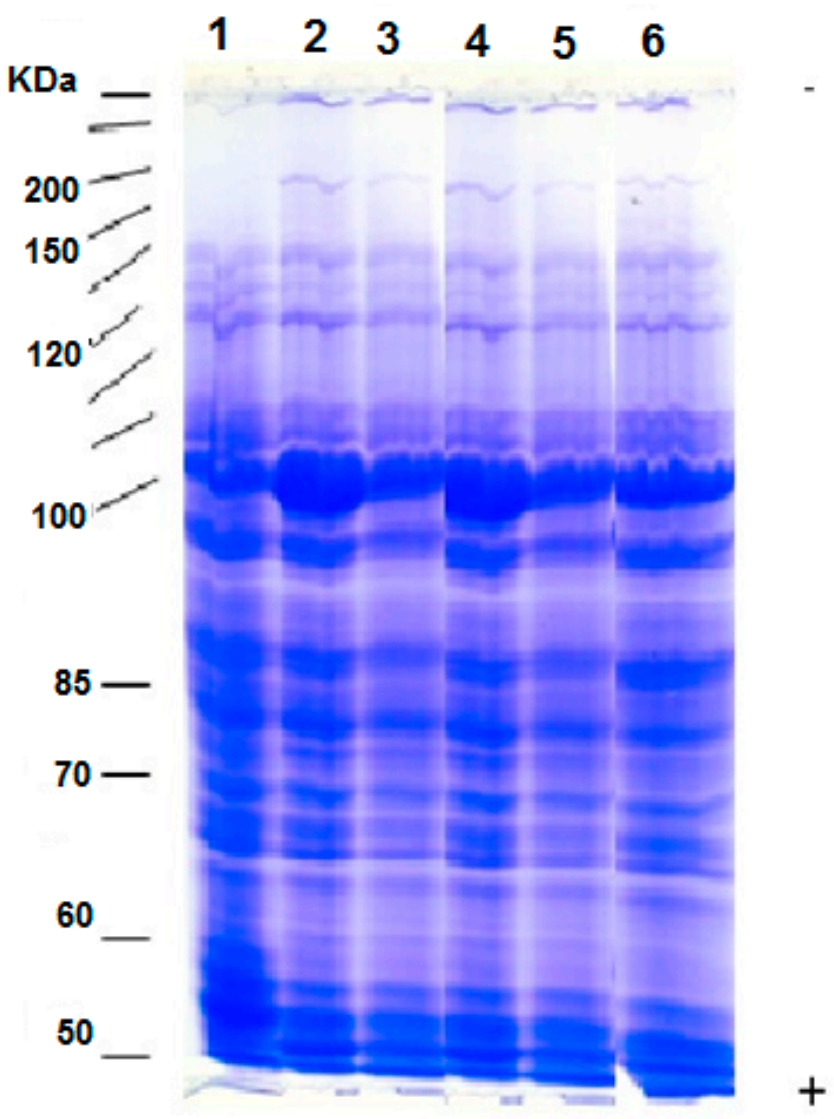

Figure 5. Analysis of protein patterns by one dimensional SDS-PAGE (13.5\% gel) extracted from wheat plants, showing the changes of protein bands, in response to salinity $(150 \mathrm{mM} \mathrm{NaCl})$ and $1 \%$ conc. (H. cuneiformis and A. fragilis extracts) treatments. Each lane contains equal amounts of protein. Protein bands in the gel were visualized by a modified Coomassie Blue staining. Lane (M): Protein markers, Lane (2): Plants treated with H. cuneiformis, Lane (3): Plants treated with A. fragilis, Lane (4): Plants treated with $\mathrm{NaCl}$, Lane (5): Plants treated with $\mathrm{NaCl}+$ H. cuneiformis and Lane (6): Plants treated with $\mathrm{NaCl}+$ A fragilis.

\section{Discussion}

4.1. Both H. cuneiformis and A. fragilis Extracts Mediated Amelioration of Salt Stress in Wheat Plants by Regulating Shoot and Root Growth

One of the growth reduction criteria in the present study was based on the negative effect of salinity on fresh and dry weight loss of roots and shoots. This was not unexpected, because the entry of toxic salt ions into the plant prevents cell division and elongation, thereby reducing growth $[42,43]$. Our results demonstrated that the application of $H$. cuneiformis or $A$. fragilis extracts not only mitigated the negative effects of salinity on the growth of wheat plants but also significantly improved the fresh and dry weight of the shoots and roots in conditions without salinity stress (Figure 3). In confirmation of our findings in wheat plants, various research studies have reported the positive effects of seaweed extracts in improving the growth of plants under salinity stress conditions [22,42,44,45]. Reference [46] similarly reported the positive effect of seed-priming with seaweed extract on wheat plants which further supported our results of the positive impact of seaweed extracts on wheat plant growth.

4.2. H. cuneiformis and A. fragilis Extracts Mediated Amelioration of Salt Stress in Wheat Plants by Regulating Physiological and Biochemical Attributes

The positive effects of seaweed extracts on chlorophyll content in the leaves might be attributed to the plant growth-promoting substances reportedly present in a variety 
of seaweed liquid fertilizers [47]. References [22,48] also reported that seaweed extracts caused improved chlorophyll and carotenoid contents which further confirm our results on the positive impact of both tested seaweed extracts on chlorophyll and carotenoid contents (Figure 4). The noticeable increase in the chlorophyll content observed in the present study has also been reported in the observation made by $[49,50]$. The positive effects of seaweed extracts on carotenoids result in protecting the macromolecules such as proteins, DNA, and RNA from the destructive effects of oxidative stress [51]. These results were supported by the results of $[22,50]$ in which physiological attributes of the plants were negatively influenced by salinity, whereas seaweed extract-treated plants showed improved physiological attributes under salt stress conditions. Our study suggested that the tested seaweed extracts provided salt stress tolerance in wheat plants and that the bioactive substances derived from the seaweeds may impart stress tolerance and enhanced plant performance. The results of the current study supported those of [22] who reported an enhanced salt tolerance due to the accumulation in seaweed extract-treated plants of phenolic compounds, thereby mediating scavenging of reactive oxygen species. The protective effects of seaweed extracts from lipid peroxidation and membrane leakage could be attributed to the presence of phenolic compounds and other active metabolites within the seaweeds [52]. H. cuneiformis and A. fragilis extracts had a protective mechanism under saline conditions by the increased production of antioxidant enzymes. Although some reports also show the beneficial anti-stress effects of seaweed extracts which may be related to cytokinin activity [53], there is still little information available on the mechanism of action of these compounds, and more studies are needed to diagnose them in the future. Increasing phenolic compounds of several plant crops in response to salinity has been previously reported [54] which further supports our results.

4.3. H. cuneiformis and A. fragilis Extracts Mediated Amelioration of Salt Stress in Wheat Plants by Regulating Ionic Balance

Plants increase the ratio of $\mathrm{K}^{+} / \mathrm{Na}^{+}$as a strategy to increase salt tolerance [55]. According to this, induced salinity stress tolerance of wheat by seaweed extracts could be due to improved $\mathrm{K}^{+}, \mathrm{Ca}^{2+}$, and $\mathrm{Mg}^{2+}$ uptake and enhanced $\mathrm{K}^{+} / \mathrm{Na}^{+}$ratio (Table 2). Seaweed extract increases the absorption of nutrients by changing the physical, biochemical, and biological properties of the soil, as well as affecting root architecture [56]. The application of seaweed extracts has been reported to enhance the $\mathrm{K}^{+}, \mathrm{Ca}^{2+}$, and $\mathrm{Mg}^{2+}$ leaf content of the plants [57], which conforms with our study on the positive effects of seaweed extracts on $\mathrm{K}^{+}$ions accumulation in leaf samples of wheat plants. In confirmation of the results of our experiment, $[20,22,58]$ similarly, reported the beneficial role of seaweed extracts in improving plant mineral uptake by the roots.

4.4. H. cuneiformis and A. fragilis Extracts Mediated the Amelioration of Salt Stress in Wheat by Preventing Oxidative Damage and Accelerating Antioxidant Enzyme Activities

The increased accumulation of MDA in leaves of wheat plants, in response to salinity stress, agreed with the findings of [3] who reported the negative effect of salinity on enhanced MDA accumulation. Reference [22] similarly reported the ameliorative effects of seaweed extracts on reducing MDA accumulation caused by salinity. Similarly, [22,59] reported that seaweed extracts enhanced the tolerance of salt stress by activating the antioxidant enzymes such as SOD, CAT and also by increasing the total phenolic compounds which contribute to the protection of plants against oxidative stress. The results of this study demonstrated that wheat plants treated with both tested seaweed extracts monitored better response in terms of all enzyme activities tested. These results coincide with the studies on Helianthus annuus [50]. Our results regarding the positive effect of seaweed extracts on increasing SOD activity of wheat plants are in accordance with the findings of [60]. Applications of seaweed extracts mitigate the oxidative stress caused by abiotic stresses via activating the antioxidant enzymes such as CAT and POD. References $[22,54,61]$ also reported that the treatment of wheat plants with seaweed extracts increased the activities of SOD and CAT. Similarly, [62] reported that the application of seaweed extracts 
resulted in enhanced SOD activity, and alleviation of the declined photochemical efficiency of turfgrass. These increments in enzyme activities might be attributed to the antioxidant compounds presented in the tested seaweed extracts in our study which is confirmed by [63]. The results of this study suggest that both tested seaweed extracts supplementation further activates the antioxidant enzymes of salt-stressed wheat plants.

\subsection{Differential Changes Were Observed in the Expression Patterns of Proteins in Wheat Plants Grown under Salinity Stress and Seaweed Extract Treatments}

References $[3,13,64]$ reported specific proteins in response to salinity stress. This finding is in agreement with those obtained by [64,65], who detected an increase in protein content in plants treated with seaweeds and moringa extracts. The appearance of new protein bands in response to the $A$. fragilis extract could be considered as treatment-specific proteins [66] or may indicate a changed pattern of gene expression [67]. On the other hand, induction of 10-15 KDa protein, with treatment by H. cuneiformis and A. fragilis extracts could also be triggered by the production of various phytohormones that are present in the seaweed extracts [68]. Moreover, the lower molecular weight proteins are known to have a profound role in the stress tolerance process [69]. Increased intensity of polypeptide bands due to applications of specific seaweed extracts used in this study might contribute to the stress tolerance of wheat plants by modulating the tolerance response. Fluctuations in the intensification of polypeptides by salinity and various seaweed extract applications might play a key role in the signaling mechanisms of the adaptive responses of wheat plants to salinity. However, the effects of seaweed extracts on protein expression are still in a state of ambiguity and further proteomic studies can provide discoveries on the influence of a wide diversity of seaweed extracts on plant metabolism under salt stress.

4.6. Possibility of Correlation between the Bioactive Compounds Detected in Extracts and Elevated Salinity Tolerance in Wheat Plants Based on GC-MS Analysis

During our GC-MS-based analyses, interestingly, each of the bioactive compounds detected in both seaweed extracts, especially those identified as the dominant components, may act as a signal pathway responsible for increasing salinity tolerance of wheat plants. In confirmation of this interpretation, some GC-MS-based detected bioactive compounds in plants have been reported to be considered as mediators of plant responses to biotic and abiotic stresses [70]. Our GC-MS studies identified the presence of important fatty acids, such as lauric acid and oleic acid in H. cuneiformis extracts and hexadecanoic acid, methyl ester, tetradecanoic acid, hexadecanoic acid, and 14-methyl-, methyl ester in A. fragilis extracts (Table 1). Accumulation of fatty acids has been reported to play a positive role against ROS and regulate the fluctuation in the signaling events of abiotic stress in plants [66,71]. The antioxidant and antibacterial properties of all the compounds detected in both seaweed extracts tested in this study have been previously reported [72-75]. Reference [76] reported the enhanced fatty acids generation of salt-tolerant plants demonstrating their positive role in confronting stress. Accordingly, our study regarding the GC-MS analysis of both seaweed extracts implies the possible role of all detected lipids in mediating salt stress tolerance of wheat plants. However, the possible underlying mechanisms or their intermediates as signaling molecules under salt stress needs to be addressed in the future.

\section{Conclusions}

This study revealed that extracts of $H$. cuneiformis and $A$. fragilis applied to wheat seeds under salinity stress improved growth performance and enhanced the tolerance of salt stress by improving photosynthetic pigments, osmolytes, phenolic compounds, $\mathrm{K}^{+}, \mathrm{Ca}^{2+}$ and $\mathrm{Mg}^{2+}$ uptakes as well as activating antioxidant enzymes (CAT, POD, and SOD) which contributed to the protection of plants against oxidative damage by reducing MDA accumulation and preventing the accumulation of toxic $\mathrm{Na}^{+}$ions. Interestingly, the differential expression of proteins in the response of salt-stressed wheat plants to priming with $H$. cuneiformis and $A$. fragilis extracts justified the positive role of both seaweed extracts in stress mitigation. Besides, GC-MS-based detected bioactive compounds were assumed to 
be the key fatty acids in wheat plants responsible for H. cuneiformis and A. fragilis extractsmediating salinity stress amelioration. However, under both salt stress and non-stressed conditions, A. fragilis extract rendered better efficacy than $H$. cuneiformis. As far as our knowledge allows, this is the first report on the application of H. cuneiformis and A. fragilis extracts in salt stress alleviation of wheat. However, the underlying mechanisms of action of bioactive compounds in these seaweeds remain unclear and need to be addressed in the future.

Author Contributions: Conceptualization, A.A.H.A.L. and E.A.A.; methodology, E.A.A.; software, E.A.A., and A.Z.; validation, A.A.H.A.L., A.Z., and E.A.A.; formal analysis, E.A.A.; investigation, A.A.H.A.L. and E.A.A.; resources, E.A.A.; data curation, A.A.H.A.L., E.A.A., and A.Z.; writingoriginal draft preparation, E.A.A. and A.Z.; writing-review and editing, A.A.H.A.L.; visualization, A.A.H.A.L. and E.A.A.; funding acquisition, A.A.H.A.L.; supervision, A.A.H.A.L. All authors have read and agreed to the published version of the manuscript.

Funding: This research was funded by Taif University Researchers Supporting Project number (TURSP-2020/72), Taif University, Taif, Saudi Arabia.

Data Availability Statement: The data presented in this study are available on request from the corresponding author.

Acknowledgments: A.Z. is thankful to the University Grants Commission, New Delhi (India) and Aligarh Muslim University, Aligarh.

Conflicts of Interest: The authors declare no conflict of interest.

\section{References}

1. Roychoudhury, A.; Singh, A.; Aftab, T.; Ghosal, P.; Banik, N. Seedling Priming with Sodium Nitroprusside Rescues Vigna radiata from Salinity Stress-Induced Oxidative Damages. J. Plant Growth Regul. 2021. [CrossRef]

2. Fariduddin, Q.; Zaid, A.; Mohammad, F. Plant Growth Regulators and Salt Stress: Mechanism of Tolerance Trade-Off. In Salt Stress, Microbes, and Plant Interactions: Causes and Solution; Springer: Singapore, 2019; pp. 91-111.

3. Osman, M.S.; Badawy, A.A.; Osman, A.I.; Abdel Latef, A.A.H. Ameliorative Impact of an Extract of the Halophyte Arthrocnemum macrostachyum on Growth and Biochemical Parameters of Soybean Under Salinity Stress. J. Plant Growth Regul. 2020. [CrossRef]

4. Yang, Y.; Guo, Y. Elucidating the molecular mechanisms mediating plant salt-stress responses. New Phytol. 2018, 217, 523-539. [CrossRef]

5. Hernández, J.A. Salinity tolerance in plants: Trends and perspectives. Int. J. Mol. Sci. 2019, 20, 2408. [CrossRef] [PubMed]

6. Munns, R.; Tester, M. Mechanisms of salinity tolerance. Ann. Rev. Plant Biol. 2008, 59, 651-681. [CrossRef]

7. Abdel Latef, A.A.H.; Kordrostami, M.; Zakir, A.; Zaki, H.; Saleh, O.M. Eustress with $\mathrm{H}_{2} \mathrm{O}_{2}$ facilitates plant growth by improving tolerance to salt stress in two wheat cultivars. Plants 2019, 8, 303. [CrossRef]

8. Abdel Latef, A.A.H.; Mostofa, M.G.; Rahman, M.; Abdel-Farid, I.B.; Tran, L.-S.P. Extracts from yeast and carrot roots enhance maize performance under seawater-induced salt stress by altering physiobiochemical characteristics of stressed plants. J. Plant Growth Regul. 2019, 38, 966-979. [CrossRef]

9. Abdel Latef, A.A.H.; Abu Alhmad, M.F.; Kordrostami, M.; Abo-Baker, A.-B.A.-E.; Zakir, A. Inoculation with Azospirillum lipoferum or Azotobacter chroococcum reinforces maize growth by improving physiological activities under saline conditions. J. Plant Growth Regul. 2020, 39, 1-14. [CrossRef]

10. Arzani, A.; Ashraf, M. Cultivated ancient wheats (Triticum spp.): A potential source of health-beneficial food products. Comp. Rev. Food Sci. Food Saf. 2017, 16, 477-488. [CrossRef] [PubMed]

11. Singh, P.; Mahajan, M.M.; Singh, N.K.; Kumar, D.; Kumar, K. Physiological and molecular response under salinity stress in bread wheat (Triticum aestivum L.). J. Plant Biochem. Biotechnol. 2020, 29, 125-133. [CrossRef]

12. Zheng, C.; Jiang, D.; Liu, F.; Dai, T.; Liu, W.; Jing, Q.; Cao, W. Exogenous nitric oxide improves seed germination in wheat against mitochondrial oxidative damage induced by high salinity. Environ. Exp. Bot. 2009, 67, 222-227. [CrossRef]

13. Abdel Latef, A.A.H. Changes of antioxidative enzymes in salinity tolerance among different wheat cultivars. Cereal Res. Commun. 2010, 38, 43-55. [CrossRef]

14. Liu, L.; Huang, L.; Lin, X.; Sun, C. Hydrogen peroxide alleviates salinity-induced damage through enhancing proline accumulation in wheat seedlings. Plant Cell Rep. 2020, 39, 567-575. [CrossRef]

15. Wani, S.H.; Kumar, V.; Khare, T.; Guddimalli, R.; Parveda, M.; Solymosi, K.; Suprasanna, P.; Kishor, P.B.K. Engineering salinity tolerance in plants: Progress and prospects. Planta 2020, 251, 76. [CrossRef] [PubMed]

16. Wani, S.H.; Dutta, T.; Neelapu, N.R.R.; Surekha, C. Transgenic approaches to enhance salt and drought tolerance in plants. Plant Gene 2017, 11, 219-231. [CrossRef] 
17. Wani, S.H.; Tripathi, P.; Zaid, A.; Challa, G.S.; Kumar, A.; Kumar, V.; Upadhyay, J.; Joshi, R.; Bhatt, M. Transcriptional regulation of osmotic stress tolerance in wheat (Triticum aestivum L.). Plant Mol. Biol. 2018, 97, 469-487. [CrossRef]

18. Van Oosten, M.J.; Pepe, O.; De Pascale, S.; Silletti, S.; Maggio, A. The role of biostimulants and bioeffectors as alleviators of abiotic stress in crop plants. Chem. Biol. Technol. Agric. 2017, 4, 5. [CrossRef]

19. Tarakhovskaya, E.R.; Maslov, Y.I.; Shishova, M.F. Phytohormones in algae. Russ. J. Plant Physiol. 2007, 54, 163-170. [CrossRef]

20. Mancuso, S.; Briand, X.; Mugnai, S.; Azzarello, E. Marine bioactive substances (IPA extract) improve ion fluxes and water stress tolerance in potted Vitis vinifera plants. Adv. Hortic. Sci. 2006, 20, 156-161.

21. El-Sharkawy, M.; El-Beshsbeshy, T.; Al-Shal, R.; Missaoui, A. Effect of plant growth stimulants on alfalfa response to salt stress. Agric. Sci. 2017, 8, 267-291. [CrossRef]

22. Abdel Latef, A.A.H.; Srivastava, A.K.; Saber, H.; Alwaleed, E.A.; Tran, L.-S.P. Sargassum muticum and Jania rubens regulate amino acid metabolism to improve growth and alleviate salinity in chickpea. Sci. Rep. 2017, 7, 1-12. [CrossRef]

23. El-Sharouny, H.M.; El-Tayeb, M.A.; Ismail, M.S. Macroalgae associated with mangroves at Hurghada and Safaga of the Egyptian Red Sea coast. J. King Abdulaziz Univ. Mar. Sci. 2001, 12, 241-251. [CrossRef]

24. Sayed, A.A.; Sadek, S.A.; Soliman, A.M.; Marzouk, M. Prospective effect of red algae, Actinotrichia fragilis, against some osteoarthritis aetiology. Afr. J. Tradit. Complement. Altern. Med. 2017, 14, 231-241. [CrossRef] [PubMed]

25. Salem, W.M.; Galal, H.; Nasr El-deen, F. Screening for antibacterial activities in some marine algae from the red sea (Hurghada, Egypt). Afr. J. Microbiol. Res. 2011, 5, 2160-2167. [CrossRef]

26. Mohamed, S.S.; Saber, A.A. Antifungal potential of the bioactive constituents in extracts of the mostly untapped brown seaweed Hormophysa cuneiformis from the Egyptian coastal waters. Egypt. J. Bot. 2019, 59, 695-708. [CrossRef]

27. Dubois, M.; Gilles, K.A.; Hamilton, J.K.; Rebers, P.A.; Smith, F. Colorimetric method for determination of sugars and related substances. Anal. Chem. 1956, 28, 350-356. [CrossRef]

28. Bradford, M.M. A rapid and sensitive method for the quantification of microgram quantities of protein utilizing the principle of protein-Dye binding. Anal. Biochem. 1976, 72, 248-254. [CrossRef]

29. Folch, J.; Lees, M.; Stanley, G.H.S. A simple method for the isolation and purification of total lipides from animal tissues. J. Biol. Chem. 1957, 226, 497-509. [CrossRef]

30. Lichtenthaler, H.K. Chlorophylls and carotenoids: Pigments of photosynthetic biomembranes. Methods Enzym. 1987, 148, 350-382.

31. Bates, L.S.; Waldren, R.P.; Teare, I.D. Rapid determination of free proline for water-stress studies. Plant Soil 1973, 39, $205-207$. [CrossRef]

32. Weidner, K.; Eggum, B. Protein hydrolysis: A description of the method used at the Department of Animal Physiology in Copenhagen. Acta Agric. Scand. 1966, 16, 115-119. [CrossRef]

33. Škerget, M.; Kotnik, P.; Hadolin, M.; Hraš, A.R.; Simonič, M.; Knez, Ž. Phenols, proanthocyanidins, flavones and flavonols in some plant materials and their antioxidant activities. Food Chem. 2005, 89, 191-198. [CrossRef]

34. Williams, V.; Twine, S. Flame photometric method for sodium, potassium and calcium. Mod. Methods Plant Anal. $1960,5,3-5$.

35. Abdel Latef, A.A.H.; Tran, L.-S.P. Impacts of priming with silicon on the growth and tolerance of maize plants to alkaline stress. Front. Plant Sci. 2016, 7, 243. [CrossRef] [PubMed]

36. Ahmad, P.; Abdel Latef, A.A.H.; Hashem, A.; Abd-Allah, E.F.; Gucel, S.; Tran, L.-S.P. Nitric oxide mitigates salt stress by regulating levels of osmolytes and antioxidant enzymes in chickpea. Front. Plant Sci. 2016, 7, 374. [CrossRef] [PubMed]

37. Maehly, A.C.; Chance, B. The assay of catalase and peroxidase. Methods Biochem. Anal. 1959, 1, 357-425.

38. Giannopolitis, C.N.; Ries, S.K. Superoxide dismutases: I. Occurrence in higher plants. Plant Physiol. 1977, 59, 309-314. [CrossRef]

39. Aebi, H. Catalase in Vitro. Methods Enzymol. 1984, 105, 121-126.

40. Laemmli, U.K. Cleavage of structural proteins during the assembly of the head of bacteriophage T4. Nature 1970, 227, 680-685. [CrossRef]

41. Studier, F.W. Analysis of Bacteriophage T4 early RNAs and proteins of slab gel. J. Mol. Biol. 1973, 79, 237-248. [CrossRef]

42. Rady, M.M.; Mohamed, G.F. Modulation of salt stress effects on the growth, physio-chemical attributes and yields of Phaseolus vulgaris L. plants by the combined application of salicylic acid and Moringa oleifera leaf extract. Sci. Hortic. 2015, 193, 105-113. [CrossRef]

43. Abdel Latef, A.A.H.; Srivastava, A.K.; El-Sadek, M.S.A.; Kordrostami, M.; Tran, L.-S.P. Titanium dioxide nanoparticles improve growth and enhance tolerance of broad bean plants under saline conditions. Land Degrad. Dev. 2018, 29, 1065-1073. [CrossRef]

44. Aymen, E.M.; Salma, L.; Halima, C.; Cherif, H.; Mimoun, E. Effect of seaweed extract of Sargassum vulgare on germination behavior of two tomatoes cultivars (Solanum Lycopersicum L.) under salt stress. Octa J. Environ. Res. 2014, 2, $203-210$.

45. Yildiztekin, K.; Tuna, A.L.; Kaya, C. Physiological effects of the brown seaweed (Ascophyllum nodosum) and humic substances on plant growth, enzyme activities of certain pepper plants grown under salt stress. Acta Biol. Hung. 2018, 69, 325-335. [CrossRef] [PubMed]

46. Chernane, H.; Latique, S.; Mansori, M.; El Kaoua, M. Salt stress tolerance and antioxidative mechanisms in wheat plants (Triticum durum L.) by seaweed extracts application. IOSR J. Agric. Vet. Sci. 2015, 8, 36-44.

47. Mostafa, M.E.; Zheekh, L. Effect of seaweed extracts on seed germination, seedling growth and some metabolic process of Vicia faba L. Cytobios 1999, 100, 23-25.

48. Blunden, G.; Jenkins, T.; Liu, Y.W. Enhanced chlorophyll levels in plants treated with seaweed extract. J. Appl. Phycol. 1996, 8, 535-543. [CrossRef] 
49. Whapham, C.A.; Blunden, G.; Jenkins, T.; Hankins, S.D. Significance of betanines in the increased chlorophyll content of plants treated with seaweed extract. Appl. Physiol. 1993, 5, 231-234.

50. Akila, N.; Jeyadoss, T. The potential of seaweed liquid fertilizer on the growth and antioxidant enhancement of Helianthus annuus L. Orient. J. Chem. 2010, 26, 1353-1360.

51. Ahmad, P.; Hashem, A.; Abd-Allah, E.F.; Alqarawi, A.A.; John, R.; Egamberdieva, D.; Gucel, S. Role of Trichoderma harzianum in mitigating $\mathrm{NaCl}$ stress in Indian mustard (Brassica juncea L.) through antioxidative defense system. Front. Plant Sci. 2015, 6, 868. [CrossRef]

52. Howladar, S.M. A novel Moringa oleifera leaf extract can mitigate the stress effects of salinity and cadmium in bean (Phaseolus vulgaris L.) plants. Ecotoxicol. Environ. Saf. 2014, 100, 69-75. [CrossRef]

53. Zhang, X.; Ervin, E.H. Cytokinin-containing seaweed and humic acid extracts associated with creeping bentgrass leaf cytokinins and drought resistance. Crop Sci. 2004, 44, 1737-1745. [CrossRef]

54. Kasim, W.A.E.A.; Khalil, M.; Saad-Allah, K.M.; Hamouda, M. Seed Priming with Extracts of two Seaweeds Alleviates the Physiological and Molecular Impacts of Salinity Stress on Radish (Raphanus sativus). Int. J. Agric. Biol. 2016, 18, 653-660. [CrossRef]

55. Azooz, M.M.; Shaddad, M.A.; Abdel-Latef, A.A.H. Leaf growth and $\mathrm{K}^{+} / \mathrm{Na}^{+}$ratio as an indication of the salt tolerance of three sorghum cultivars grown under salinity stress and IAA treatment. Acta Agric. Hung. 2004, 52, 287-296. [CrossRef]

56. Battacharyya, D.; Babgohari, M.Z.; Rathor, P.; Prithiviraj, B. Seaweed extracts as biostimulants in horticulture. Sci. Hortic. 2015, 196, 39-48. [CrossRef]

57. Fei, H.; Crouse, M.; Papadopoulos, Y.; Vessey, J.K. Enhancing the productivity of hybrid poplar (Populus $\times$ hybrid) and switchgrass (Panicum virgatum L.) by the application of beneficial soil microbes and a seaweed extract. Biomass Bioenergy 2017, 107, 122-134. [CrossRef]

58. Vernieri, P.; Borghesi, E.; Ferrante, A.; Magnani, G. Application of biostimulants in floating system for improving rocket quality. J. Food Agric. Environ. 2005, 3, 86-88.

59. Latique, S.; Chernane, H.; Mansori, M.; El Kaoua, M. Biochemical modification and changes in antioxidant enzymes in Triticum durum L. by seaweed liquid extract of Ulva rigida macroalgae under salt stress condition. Adv. Environ. Res. 2016, 50, 35-54.

60. Fike, J.H.; Allen, V.G.; Schmidt, R.E.; Zhang, X.; Fontenot, J.P.; Bagley, C.P.; Ivy, R.L.; Evans, R.R.; Coelho, R.W.; Wester, D.B. Tasco-Forage: I. Influence of a seaweed extract on antioxidant activity in tall fescue and in ruminants. J. Anim. Sci. 2001, 79, 1011-1021. [CrossRef]

61. Ibrahim, W.M. Potential Impact of Marine Algal Extracts on the Growth and Metabolic Activities of Salinity Stressed Wheat Seedlings. J. Appl. Sci. 2016, 16, 388-394. [CrossRef]

62. Zhang, X.; Schmidt, R. Antioxidant response to hormone-containing product in Kentucky Bluegrass subjected to drought. Crop Sci. 1999, 39, 545-551. [CrossRef]

63. Tuna, A.L.; Kaya, C.; Altunlu, H.; Ashraf, M. Mitigation effects of non-enzymatic antioxidants in maize (Zea mays L.) Plants under salinity stress. Aust. J. Crop Sci. 2013, 7, 1181-1188.

64. Abdel Latef, A.A.H.; Abu Alhmad, M.F.; Hammad, S.A. Foliar application of fresh moringa leaf extract overcomes salt stress in Fenugreek (Trigonella foenum-graecum) plants. Egypt. J. Bot. 2017, 57, 157-179.

65. Mohiuddin, M.; Das, A.K.; Ghosh, D.C. Growth and productivity of wheat as influenced by integrated use of chemical fertilizer, biofertilizer and growth regulator. Indian J. Plant Physiol. 2000, 5, 334-338.

66. Kang, K.; Park, S.; Kim, Y.S.; Lee, S.; Back, K. Biosynthesis and biotechnological production of serotonin derivatives. Appl. Microbiol. Biotechnol. 2009, 83, 27-34. [CrossRef]

67. Popova, L.P.; Stoinova, Z.G.; Maslenkova, L.T. Involvement of abscisic acid in photosynthetic process in Hordeum vulgare L. during salinity stress. J. Plant Growth Regul. 1995, 14, 211-218. [CrossRef]

68. Davies, P.J. The Plant Hormones: Their Nature, Occurence, and Function; Springer: Dordrecht, The Netherlands, 1995.

69. Xu, D.; Duan, X.; Wang, B.; Hong, B.; Ho, T.H.D.; Wu, R. Expression of a late embryogenesis abundant protein gene, HVA1, from barley confers tolerance to water deficit and salt stress in transgenic rice. Plant Physiol. 1996, 110, 249-257. [CrossRef]

70. Liu, X.; Ma, D.; Zhang, Z.; Wang, S.; Du, S.; Deng, X.; Yin, L. Plant lipid remodelling in response to abiotic stresses. Environ. Exp. Bot. 2019, 165, 174-184. [CrossRef]

71. Kaur, H.; Mukherjee, S.; Baluska, F.; Bhatla, S.C. Regulatory roles of serotonin and melatonin in abiotic stress tolerance in plants. Plant Signal. Behav. 2015, 10, e1049788. [CrossRef]

72. Rahuman, A.; Gopalakrishnan, G.; Ghouse, B.; Arumugam, S.; Himalayan, B. Effect of Feronia limonia on mosquito larvae. Fitoterapia 2000, 71, 553-555. [CrossRef]

73. Kumar, P.P.; Kumaravel, S.; Lalitha, C. Screening of antioxidant activity, total phenolics and GC-MS study of Vitex negundo. Afr. J. Biochem. Res. 2010, 4, 191-195.

74. Chandrasekaran, M.; Senthilkumar, A.; Venkatesalu, V. Antibacterial and antifungal efficacy of fatty acid methyl esters from leaves of Sesuvium portulacastrum L. Eur. Rev. Med. Pharm. Sci. 2011, 15, 775-780.

75. Awa, E.P.; Ibrahim, S.; Ameh, D.A. GC/MS analysis and antimicrobial activity of diethyl ether fraction of methanolic extract from the stem bark of Annona senegalensis Pers. Int. J. Pharm. Sci. Res. 2012, 3, 4213-4218.

76. Gupta, P.; De, B. Metabolomics analysis of rice responses to salinity stress revealed elevation of serotonin, and genetic acid levels in leaves of tolerant varieties. Plant Signal. Behav. 2017, 12, e1335845. [CrossRef] [PubMed] 